\title{
Insecticidal Activity of Extracellular Protein of PRU8 Isolate against Tenebrio molitor Larvae
}

\author{
Aktivitas Insektisidal Protein Ekstrasel Isolat PRU8 terhadap Larva Tenebrio molitor
}

\author{
Alina Akhdiya*, Etty Pratiwi, I Made Samudra \\ Balai Besar Penelitian dan Pengembangan Bioteknologi dan Sumberdaya Genetik Pertanian \\ Jl. Tentara Pelajar 3A, Cimanggu, Bogor 16111 \\ E-mail:a2khdiyar@yahoo.co.uk *Penulis untuk korespondensi
}

\begin{abstract}
Abstrak
Sel ataupun supernatan bebas sel dari kultur cair isolat bakteri entomopatogen PRU8 memiliki toksisitas tinggi terhadap larva Tenebrio molitor. Bioesei protein ekstrasel kasar hasil pengendapan amonium sulfat menunjukkan bahwa toksisitas tertinggi terdapat pada protein yang diendapkan pada kejenuhan amonium sulfat $70 \%$. Pemurnian protein menggunakan kolom Hi Prep 16/60 Sephacryl S-200 HR menghasilkan satu fraksi protein toksin. Mortalitas larva uji yang disuntik dengan 19,2 nanogram toksin murni mencapai 71\%. Uji toksisitas menggunakan toksin murni menunjukkan bahwa toksin tersebut termasuk kelompok toksin tipe injeksi. Berdasarkan analisa SDS-PAGE toksin tersebut tersusun atas dua protein dengan berat molekul 116,25 dan 66,24 kDa.
\end{abstract}

Kata kunci: Insektisidal, protein toksin, entomopatogen, Tenebrio molitor

Diterima: 25 Maret 2008, disetujui: 25 Februari 2009

\section{Introduction}

Naturally enthomopathogens are
important regulatory factors in insect
populations. Many species are employed as
biological control agents of insect pests in row
and glasshouse crops, orchards, ornamentals,
range, turf and lawn, stored products, forestry,
and for abatement of pest and vector insects of
veterinary and medical importance. Public
concern on environmental friendly biological
control has stimulated scientists to study
potency of enthomopathogens as pest biological
controls (Ertürk and Demirbağ, 2006).
Application of enthomopathogens as a
pest biological control was introduced in 19
century. However it has been broadly applied
when Bacillus thuringiensis was produced as a
commercial bioinsecticide. Currently, various
bacterial enthomopathogens are used as
bioinsecticides to control crop pests and insect

vectors of human and veterinary diseases (Lacey et al., 2001).

Some enthomopathogenic bacteria are commercially produced as bioinsecticides such as $B$. thuringiensis, Serratia enthomophila (Hurst et al., 2000; Townsend et al., 2004), B. laterosporus (Justo de Oliveira et al., 2004), Paenibacillus popilliae (Klein, 1992), Pseudomonas flourescens (California Department of Pesticides Regulation, 2007), Pseudomonas chlororaphis (REBECA, 2006), and Serratia plymuthica (REBECA, 2006).

Pathogenicity of a bacterial entomopathogen is caused by either intracellular or extracellular protein toxins. B. thuringiensis produces a parasporal body that is known as $\delta$ endotoxin proteins. Enthomopathogenic strains of Serratia sp. produce a Sep protein that is similar to insecticidal protein toxin (Tc) of Photorhabdus (Hurst et al., 2000). And some strains of Pseudomonas sp. produce not only a Tc-group toxin (Jander et al., 2000), but also 
enzymes in their outer membrane vesicles (Meta and Kesty, 2005).

PRU8 bacterial isolate is a bacterium collected by Balai Besar Bioteknologi dan Sumberdaya Genetik Pertanian, Badan Litbang Pertanian, Departemen Pertanian. Preliminary toxicity study of the isolate against Tenebrio molitor larvae showed that the isolate was highly toxic to the larvae (Pratiwi et al., 2005). Therefore the aims of this study were to characterize the insecticidal proteins and to determine toxicity of the protein against Tenebrio molitor larvae.

\section{Materials and Methods}

\section{Materials}

Media and reagents used in this study were Nutrient Bromthymol Blue Tetrazolium Choride Agar (NBTA; Nutrient Broth 8 g/l, Bromothymol Blue $0.025 \mathrm{~g} / \mathrm{l}$, Triphenyltetrazolium Chloride $0.04 \mathrm{~g} / \mathrm{l}$ ), Luria Bertani (LB; $\mathrm{NaCl} 10 \mathrm{~g} / \mathrm{l}$, triptone $10 \mathrm{~g} / \mathrm{l}$, yeast extract $5 \mathrm{~g} / \mathrm{l}$ ), PBS (phosphate buffer saline) solution $\left(\mathrm{NaCl} 8 \mathrm{~g} / \mathrm{l}, \mathrm{KCl} 0,2 \mathrm{~g} / \mathrm{l}, \mathrm{Na}_{2} \mathrm{HPO}_{4}\right.$ $1,15 \mathrm{~g} / 1, \mathrm{KH}_{2} \mathrm{PO}_{4}$ 0,2 g/l), ammonium sulphate, Protein Assay reagents (Bio-Rad), Protein Assay Standard II (Bio-Rad), sodium dedocyl sulphate (SDS), acrilamide, methylene-bisacrilamide, Tris $\mathrm{HCl} \mathrm{pH}$ 6,8 and, TEMED (N,N,N',N' - tetramethylene - ethylenediamine), ammonium persulphate, Tris-base, bromphenol blue, $\quad \beta$-mercaptoethanol, $\quad$ glycerol, trichloroacetic acid (TCA) 20\%, methanol, acetic acid, Coomassie Brilliant Blue R-250, Low Range molecular weight standard proteins (Biorad, USA).

\section{Cultivation and insecticidal protein production}

PRU8 isolate is a bacterial collection of Balai Besar Penelitian dan Pengembangan Bioteknologi dan Sumberdaya Genetik Pertanian-Bogor. This bacterium was isolated from soil in Pelabuhan Ratu Sukabumi. The bacterium was recultured on NBTA medium. Production of insecticidal proteins was carried out using $500 \mathrm{ml}$ of LB media. As much as 1 $\mathrm{ml}$ culture of the bacterium was inoculated into the production media. Incubation was held at room temperature for 48 hours on rotary orbital shaker at $125 \mathrm{rpm}$.

\section{Purification of insecticidal proteins}

The bacterial culture was centrifuged at $15,000 \mathrm{rpm}$ and $4^{\circ} \mathrm{C}$ for 30 minutes. Cellular precipitate was discarded and supernatant liquid was gradually added and carefully stirred by ammonium sulphate up to 60,70 and $80 \%$ saturation. After overnight incubation in a refrigerator, the solution was centrifuged at $17,000 \mathrm{rpm}$ and $4^{\circ} \mathrm{C}$ for 30 minutes. Precipitated proteins were diluted in $\mathrm{pH} 7.3$ PBS solution. Then dialysis was held overnight using $\mathrm{pH} \quad 7.3$ PBS solution. Insecticidal proteins were purified using Hi Prep 16/60 Sephacryl S-200 High Resolution (HR) columns of AKTA Purifier Chromatograph (Pharmacia). Elution was used pH 7.3 PBS solution with flow rate at $0.3 \mathrm{ml} /$ minute and the detector was set up at $280 \mathrm{~nm}$. Protein fractions were automatically collected using a fraction collector.

\section{Determination of protein concentration}

Protein concentration was determined based on Bradford (1976) method using a Protein assay kit (Bio-Rad).

\section{SDS-PAGE electrophoresis analysis}

Sample and standard proteins were heated for 10 and 5 minutes respectively. And as much as $20 \mu \mathrm{l}$ of the samples and standard were loaded into wells of $12.5 \%$ homogenous gel. Electrophoresis was run at 100 volts for 2 hours. Coomassie Brilliant Blue staining was used for visualization of the results. Gel was deep down into 20\% TCA solution for 15 minutes and then stained using Coomassie Brilliant Blue R-250 for 15 minutes. Excess of staining solution was rinsed using methanol: acetic-acid: distillated water (1:1:8) solution up to clearly turning up of blue color of protein bands.

Standard curves of high and low molecular weight proteins were designed by plotting of molecular weight log values with Rf values. Rf values were calculated using a formula as described below. 


$$
\mathrm{Rf}=\frac{\text { Moving distance of a protein band }}{\text { Moving distance of bromphenol blue }}
$$

And molecular weight of insecticidal protein was determined by calculating an $\mathrm{Rf}$ value of an insecticidal protein band using the standard curve equation.

\section{Bioassay}

Bioassay of crude and purified insecticidal proteins was carried out by either oral or direct injection into haemolyph of Tenebrio molitor larvae $\left(3^{\text {rd }}-4^{\text {th }}\right.$ instars $)$ applications. Direct injection bioassay was managed by injection of $1 \mu \mathrm{l}$ insecticidal proteins through intersegment into haemolyph of the larvae (Brown et al., 2004). Oral bioassay was managed by dropping of $250 \mu \mathrm{l}$ either crude or purified insecticidal proteins to 1 gram of artificial feeds which has mentioned by Miyahara (1977). The proteins were gradually dropped so that they were adsorbed. The feed was then left on a laminar air flow cabinet to be dried.

PBS solution without insecticidal protein was used as negative controls either for oral or direct injection application. Each treatment was employed with 3 replicates and each replicate used 15 larvae. Mortality of the larvae was observed daily up to 2 days of incubation.

\section{Results and Discussions}

\section{Insecticidal protein precipitation and bioassay}

Commonly, optimalization of protein precipitation using ammonium sulfate was the first step of protein purification. Precipitation results using serial concentration of saturated ammonium sulfate are shown at Table 1 . The results indicated that total precipitated protein recovery was increased by increasing of ammonium sulfate saturation percentages. The total precipitated protein recovery of $99 \%$ was achieved at $80 \%$ saturation of ammonium sulfate.

Determination of a good saturation level for precipitation of the insecticidal proteins should be confirmed by a toxicity bioassay using serial concentration of precipitated proteins. Toxicity bioassay results of the precipitated proteins are shown at Table 2 . The proteins precipitated using $70 \%$ saturation of ammonium sulfate had the highest mortality of Tenebrio molitor larvae. The $\mathrm{MC}_{50} \quad(50 \%$ mortality concentration) values of the precipitated proteins were calculated using linear regression analysis. The $\mathrm{MC}_{50}$ values of the proteins precipitated using $60 \%, 70 \%$, and $80 \%$ saturation of ammonium sulfate were $0,226, \quad 0.200$, dan $0,266 \mathrm{mg}$ protein $/ \mathrm{ml}$ respectively (Table 3 ).

Table 1. Results of protein precipitation of PRU8 culture supernatant and their protein recovery

\begin{tabular}{cccccc}
\hline \hline $\begin{array}{c}{\left[\mathbf{N H}_{4}\right]_{2} \mathbf{S O}_{4}} \\
\text { Saturation } \\
(\%)\end{array}$ & $\begin{array}{c}\text { Volume } \\
(\mathbf{m l})\end{array}$ & $\begin{array}{c}\text { Supernatant } \\
\text { Protein Concentration } \\
(\mathbf{m g} / \mathbf{m l})\end{array}$ & $\begin{array}{c}\text { Volume } \\
(\mathbf{m l})\end{array}$ & $\begin{array}{c}\text { Dialisate } \\
\text { Protein Concentration } \\
(\mathbf{m g} / \mathbf{m l})\end{array}$ & $\begin{array}{c}\text { Total Protein } \\
\text { Recovery } \\
(\mathbf{\%})\end{array}$ \\
\hline \hline 60 & & & 0.90 & 0.556 & 67.66 \\
70 & $75 \mathrm{ml}$ & 0.01008 & 1.00 & 0.607 & 80.29 \\
80 & & & 0.90 & 0.832 & 99.04 \\
\hline \hline
\end{tabular}

Table 2. Toxicity bioassay results of precipitated proteins against Tenebrio molitor larvae incubated for 48 hours

\begin{tabular}{|c|c|c|c|c|c|c|}
\hline \multirow{3}{*}{$\begin{array}{c}\text { Protein Concentration } \\
(\mathrm{mg} / \mathrm{ml})\end{array}$} & \multicolumn{6}{|c|}{ Number of dead larvae treated by precipitated proteins (larvae) } \\
\hline & \multicolumn{2}{|c|}{$60 \%\left(\mathrm{NH}_{4}\right)_{2} \mathrm{SO}_{4}$} & \multicolumn{2}{|c|}{$70 \%\left(\mathrm{NH}_{4}\right)_{2} \mathrm{SO}_{4}$} & \multicolumn{2}{|c|}{$80 \%\left(\mathrm{NH}_{4}\right)_{2} \mathrm{SO}_{4}$} \\
\hline & Average & std.err. & Average & Std.err. & Average & std. err. \\
\hline 0.125 & 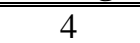 & $\overline{\overline{0}}$ & $\overline{\overline{5}}$ & 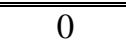 & $\overline{\overline{4}}$ & 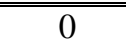 \\
\hline 0.250 & 9 & 0 & 9.67 & 0.33 & 7.33 & 0.33 \\
\hline 0.375 & 11.67 & 0,33 & 12 & 0 & 10 & 0 \\
\hline 0.500 & 15 & 0 & 15 & 0 & 15 & 0 \\
\hline Kontrol (PBS) & \multicolumn{6}{|c|}{0} \\
\hline
\end{tabular}

Std. err.: standart error 
Data at Table 2 and 3 indicated that $70 \%$ saturation of ammonium sulfate was the best concentration of ammonium sulfate to precipitate insecticidal toxins of PRU8 isolate. On the other hand, $80 \%$ saturation of ammonium sulfate had the highest total protein recovery (up to $99 \%$ ), but it had a low larval mortality value. This result indicated that $80 \%$ saturation of ammonium sulfate precipitated a lot of non-toxic proteins.

\section{Purification of insecticidal proteins}

Purification of crude toxic proteins using Hi Prep 16/60 Sephacryl S-200 HR column performed 4 fractions namely U1, U2, U3 and U4 fractions (Figure 1.A). U1 fraction was the highest peak, while the other peaks were low peaks on the chromatograph. All protein fractions toxicity was tested against Tenebrio molitor larvae to determine which fraction was the insecticidal protein fraction. Bioassay (toxicity test) by injecting 19.2 nanogram fractionated protein per larvae was confirmed that U1 fraction was the insecticidal protein toxin. It had larval mortality up to $71 \%$ (Table 4). On the other hand bioassay results of oral application showed that none of the fractions was toxic to $T$. molitor larvae.

Characterization of the insecticidal protein toxin using SDS-PAGE indicated that U1 fraction (a toxic fraction) was composed of two proteins. Molecular weights of the proteins were 116.25 and $66.4 \mathrm{kDa}$ respectively (Figure 1.B). This result could not explain whether both proteins were a sub unit protein of insecticidal protein toxin or each protein had its toxic activity. Therefore subsequent study had to be conducted to determine toxicity of the insecticidal proteins as stated above.

Table 3. The $\mathrm{MC}_{50}(50 \%$ mortality concentration) values of the precipitated proteins calculated using linear regression analysis.

\begin{tabular}{ccc}
\hline \hline $\left.\mathbf{N H}_{4}\right]_{2} \mathbf{S O}_{\mathbf{4}}$ saturation (\%) & $\mathbf{M C}_{\mathbf{5 0}}$ value $(\mathbf{m g} / \mathbf{m l})$ & $\mathbf{r}^{2}$ value of linear regression \\
\hline \hline 60 & 0,226 & 0,9702 \\
70 & 0,200 & 0,9641 \\
80 & 0,266 & 0,9960 \\
\hline \hline
\end{tabular}

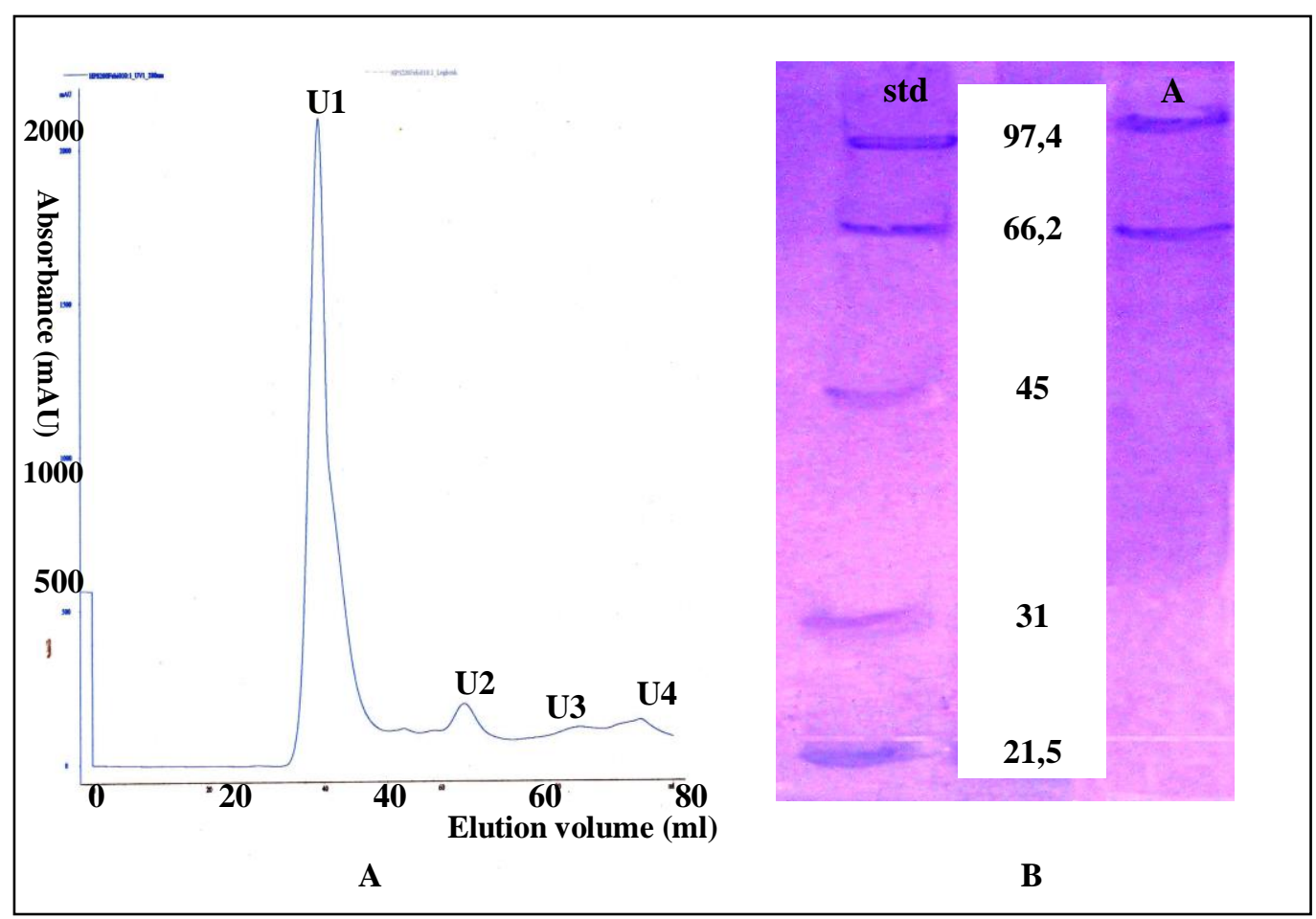

Figure 1. A. Chromatograph of a toxic protein purified using Hi Prep 16/60 Sephacryl S 200 HR column. B. SDS PAGE results of a toxic protein.

(Std: standard of low molecular weight proteins, A: U1 fraction). 
Table 4. Toxicity of protein fractions against Tenebrio molitor larvae.

\begin{tabular}{ccc}
\hline \hline Fractioni & Average of dead larvae & Std. err. \\
\hline \hline U1 & 10,67 & 0,33 \\
U2 & 0 & 0 \\
U3 & 0 & 0 \\
U4 & 0 & 0 \\
\hline \hline
\end{tabular}

\section{References}

Brown, S.E., Cao, A.T., Hines, E.R., Akhrust, R.J. and East, P.D. 2004. A novel secreted protein toxin from the insect pathogenic bacterium Xenorhabdus nematophila. The J. Biol. Chem. 279 (15): 14595-14601.

California Department of Pesticides Regulation. 2007. http://www.cdpr.ca.gov/docs/pur/pur00rep/tab le00/table10a.htm.05/01/2008.

Ertürk, Ö. and Demirbağ, Z. 2006. Studies on bacterial flora and biological control agent of Cydia pomonella L. (Lepidoptera: Tortricidae). African J. Biotechnol. 5 (22): 2081-2085.

Hurst, M.R.H., Glare, T.R., Jackson, T.A. and Ronson, C.W. 2000. Plasmid-located pathogenicity determinants of Serratia enthomophila, the causal agent of amber disease of grass grub, show similarity to the insecticidal toxins of Photorhabdus luminescens. J. Bacteriol. 182: 5127-5138.

Jander, G., Rahme, L.G. and Ausubel, F.M. 2000. Positive corretation between virulence of Pseudomonas aeruginosa mutans in mice and insects. J. Bacteriol. 182: 3843-3845.

Justo de Oliveira, E., Rabinovitch, L., Monnerat, R.G., Passos, L.K.J. and Zahner, V. 2004. Molecular characterization of Breivibacillus laterosporus and its potential use in biological control. Appl. Environ. Microbiol 70 (11): 6657-6664.
Klein, M.G. 1993. Use of Bacillus popilliae in Japanese beetle control. In: Jackson, T.A. and Glare, T.R. (Eds.). The Use of Pathogens in Scarab Pest Management. Intercept Book. Andover, M.D. pp. 179-189.

Lacey, L.A., Frutos, R., Kaya, H.K. and Vail, P. 2001. Insect pathogens as biological control agents: do they have a future? Biol. Control. 21: 230248.

Meta, J.K. and Kesty, N.C. 2005. Bacterial outer membrane vesicles and the host-pathogen interaction. Genes \& Dev. 19: 2645-2655.

Pratiwi, E., Akhdiya, A. dan Samudra, I.M. 2005. Eksplorasi Gen Penyandi Toksin Insektisidal dari Bakteri Simbion Nematoda Patogen Serangga. Laporan Hasil Penelitian Balai Besar Bioteknologi dan Sumberdaya Genetik Pertanian Tahun 2005.

REBECA. 2006. List of Ducuments with relevance for the REBECA Workshop at 18.-22.09.2006 in Salzau Germany. http://www.rebecanet.de/downloads/REBECASalzauDocument/ document $\% 20$ links.pdf. 12/20/2007.

Townsend, R.J., Jackson, T.A., Ferguson, C.M., Proffitt, J.R., Slay, M.W.A., Swaminathan, J., Day, S., Gerard, E.M., O'Callaghan, M. and Johnson, V.W. 2004. Establishment of Serratia enthomophila after application of a new formulation for grass grub control. NZ Plant Protection. 57: 310-313. 